\title{
The Role of Fun at Work towards Job Satisfaction of Employee with Work Engagement as Mediator
}

\author{
Yan Ayu Permatasari* | Asri Laksmi Riani \\ Faculty of Economics and Business, Universitas Sebelas Maret, Indonesia
}

\begin{abstract}
The purpose of this study is to examine the effect of fun at work on job satisfaction with work engagement as a mediation variable. Specifically, this study is intended is to find out the relationship between fun at work and work engagement, fun at work and work satisfaction, and fun at work and work satisfaction mediated by work engagement. Data were collected through surveys and conducted by distributing questionnaires to the company. The sampling technique used is a saturation sampling method, which all members of the population were used as the sample. The sample consisted of 65 respondents. The results of this study suggests that fun at work significantly affects work engagement. In addition, work involvement indirectly mediates between fun at work and job satisfaction. This phenomenon possibly can occur because a fun workplace can stimulate a good mood and excitement for employees in doing their job.
\end{abstract}

Keywords: fun at work, job engagement, job satisfaction

\section{Introduction}

One of the most popular types of organizational climate to create a comfortable and fun environment for employees is fun at work. Fun at work is one type of organizational climate that began to be applied in several companies in the current era of globalization (Yanti, 2013). A comfortable workplace can reduce the level of stress and maximize employees in performing the tasks assigned by their superior. In and Ching (2010) mentioned that workers in Hong Kong are regarded as a group of workers who have the highest level of worry, anxiety, and unhappy feeling in the world. A fun workplace can affect employees in the work to feel better and this will increase their motivation and productivity in the work. Basically, fun at work involves fun activities that are designed deliberately to improve organizational performance (Lamm and Meeks, 2009).

Fun at work could be described as an activity that is not specifically related to the work with fun, entertaining, and full of fun (McDowell, 2014). A fun work atmosphere is set up to create working conditions to become more comfortable, open, and fun. According to Fluegge (2014), pleasant experience of working will increase job satisfaction. Individuals who get greater fun at workplace have lower emotional rates of fatigue.

Individuals who feel happy at work also tend to be more involved in work with a larger creative level (Fluegge, 2014). Jamaludin et al. (2014) stated that the level of work involvement will be lower

\footnotetext{
* Corresponding author at Jl. Ir Sutami No.36 A, Pucangsawit, Kec. Jebres, Kota Surakarta, Jawa Tengah 57126. Email: yan.ayu23@gmail.com
} 
if there is no pleasure in the workplace and this will affect the goals of the organization. Nowadays managers see that having fun at work could create a positive environment to motivate their employees. Questions for this research are: First, Does fun at work impact work engagement? Second, does fun at work impact the job satisfaction? Third, does work engagement effect to fun at work and job satisfaction?

\section{Hypothesis development}

\section{The influence of Fun at work on job involvement}

Individuals who feel fun or happy at the workplace tend to be more involved in work with a greater creative level (Fluegge, 2014). According to Jamaludin et al. (2014), Individuals who feel fun at work will have a high level of job involvement. The higher level of fun at the workplace, then the more driven the individual into doing the work. This description leads to the following hypothesis:

\section{H1: There is influence in fun at wok on work engagement}

\section{The influence of Fun at work on employee satisfaction}

According to Lamm and Meeks (2009), One of the factors that influence the creation of job satisfaction behavior is a fun workplace. In, In and Ching (2010), Workplace pleasure is positively related to job satisfaction. According to Fluegge (2014), Fun at workplace is very important in performing a positive environment. A positive environment could affect a person's mood better. Individuals feeling fun at work often tend to involve in work and will have an effect towards creative and greater performance. Therefore the second hypothesis of this study is:

\section{H2: There is influence in fun at work on job satisfaction}

\section{Job involvement mediates fun at work with job satisfaction}

Fluegge (2008), if employees feel fun at work then they tend to be more involved in their work, and indirectly affects on job performance". Schaufeli (2013)revealed Job involvement is a positive motivation,to fulfill and affect employees in work related to welfare in improving company performance. Fluegge (2014) explained that If workplace fun enhances job engagement, which positively affects performance outcomes, then work involvement mediates the relationship between workplace fun and performance outcomes. Therefore the third hypothesis of this research is:

H3: There is influence in fun at work on job satisfaction through mediation factor of work engagement.

\section{Research Model}

Based on the three formulated hypothesis, the relationship among conceptual variables is shown in model below (see Figure 1). It describes the relationship framework of the variables.

Figure 1. The theoretical framework






\section{Research Methods}

\section{Data collection and Sample Method}

Researchers used a census population research study where the entire population were used as a sample of research. This is due to the numbers of population of 65 people in this study is considered relatively small. The samples in this study are employees who have a working period of more than 3 months or permanent employees. Subsequently, data were collected using a questionnaires, which were distributed directly in the company.

\section{Fun at work}

Fun at work is meant to provide socialization, and interpersonal relationships intended to provide entertainment, and excitement within the company (Lamm and Meeks, 2009). Fun at work is one type of organizational climate that began to be applied in some companies in the current era of globalization (Yanti, 2013). According to Fluegge (2008) Fun at work is described as engaging an individual socially, interpersonally, doing a fun and humorous job in which the atmosphere can provide an entertaining, comfortable, and fun atmosphere. According to McDowell in Jamaludin et al. (2014), Fun at work is defined as activities that indirectly related to pleasure, fun and playful work.

According to Fluegge (2014), Jamaludin et al. (2014), and McDowell (2014) measured the fun at work scale can be measured using four following dimensions socializing at work, Celebrating at Work, Personal Freedoms, Global Fun at Work.

\section{Job satisfaction}

Job satisfaction is a part of a life's sustainability that is related to the feelings and attitudes of a person to his work. Job satisfaction is measured by three item scales from the Michigan Organizational Assessment Questionnaire (Lamm and Meeks, 2009). The measurement items are all in all, I am satisfied with my job, in general, I like working here, in general, I do not like my job.

\section{Work Engagement}

According to Fluegge (2014), work engagement concerns the extent to which individuals use their cognitive, emotional, and physical resources entirely. Schaufeli (2013) revealed work engagement is a positive motivation, fulfillment and affect of employees in work related to welfare. Three Dimensions of Job Engagement according to Fluegge (2014) and Schaufeli (2013) are Vigor, Dedication, Absorption.

\section{Data Analysis}

Methods of data analysis used in this study is descriptive analysis. Descriptive analysis is the general picture of respondent's profiles and characteristics of respondent (age, gender, educational background). Test of research instrument used validity and reliability test, meanwhile hypothesis test used SPSS (Statistical Package for Social Science) for Windows Baron \& Kenny's regression method (Barron and Kenny, 1986).

The general form of the regression equation are as follow:

$\mathrm{E}=\mathrm{a}+\mathrm{b} 1 \mathrm{Sw}+\mathrm{b} 2 \mathrm{Cw}+\mathrm{b} 3 \mathrm{Pf}+\mathrm{b} 4 \mathrm{Gf}+\mathrm{e}$

$\mathrm{JS}=\alpha+\mathrm{b} 1 \mathrm{Sw}+\mathrm{b} 2 \mathrm{Cw}+\mathrm{b} 3 \mathrm{Pf}+\mathrm{b} 4 \mathrm{Gf}+\mathrm{e}$

$\mathrm{JS}=\alpha+\mathrm{b} 1 \mathrm{Sw}+\mathrm{b} 2 \mathrm{Cw}+\mathrm{b} 3 \mathrm{Pf}+\mathrm{b} 4 \mathrm{Gf}+\mathrm{b} 5 \mathrm{E}+\Sigma \ldots \ldots$.

$\mathrm{E}=$ Job Engagement

JS $=$ Job satisfaction

$\mathrm{Sw}=$ Socializing with Coworkers

$\mathrm{Cw}=$ Celebrating at Work

$\mathrm{Pf}=$ Personal Freedoms

Gf $=$ Global Fun at Work 


\section{Result and Discussion \\ Descriptive Analysis}

Descriptive analysis is intended to find out response and characteristics of respondents. Characteristics of respondents consist of four demographic informations: age, sex, education, and years of service. Demographic information is expected to provide an overview of the customer's background (see Table 1)

Tabel 1. Descriptive Statistics

\begin{tabular}{lcc}
\hline Characteristics & $\begin{array}{c}\text { Number of } \\
\text { Respondents }\end{array}$ & Percentage(\%) \\
\hline A. Age (Years Old) & & \\
$\quad<20$ & 4 & 6.2 \\
$20-30$ & 20 & 30.8 \\
$31-40$ & 18 & 27.7 \\
$41-50$ & 16 & 24.6 \\
$\quad 51-\quad 60$ & 7 & 10.8 \\
Amount & 65 & 100.0 \\
B. Sex & & \\
Man & 22 & 33.8 \\
$\quad$ Woman & 43 & 66.2 \\
Amount & 65 & 100.0 \\
C. Education & & \\
Elemantary School & 1 & 1.5 \\
Junior High School & 14 & 21.5 \\
Senior High School & 41 & 63.1 \\
Bachelor & 9 & 13.8 \\
Amount & 155 & 100.0 \\
D. Working Period & & \\
$\quad$ 5 years & 30 & 46.2 \\
5-10 years & 18 & 27.7 \\
$\quad>$ 10 years & 17 & 26.2 \\
Amount & 65 & 100,0 \\
\hline
\end{tabular}

Table 1. shows that the number of respondents based on the most ages is between 20-30 years old at $30.8 \%$ and the smallest is $>20$ years old ie $6.2 \%$. Based on the sex, of the female respondents are equal to 43 persons $(66.2 \%)$ and male respondents are equal to 22 persons $(33.8 \%)$. The most respondent's education is senior high school graduation $(41.1 \%)$ and the lowest is one person of elementary school $(1.5 \%)$. In the working period of respondents as seen in table 1 , the data obtained were mostly $<5$ years of 30 persons (46.2\%), 5-50 years work experience of $18(27.7 \%)$ and $>10$ years of 17 persons.

Based on Table 2, it can be seen that the average fun at work of socializing with coworker dimension has an agreed assessment. The average score of respondents' assessment of the fun at work variable of socializing with coworker is 3.96 (at interval $3.41-4.20$ ), which means that some respondents have high socializing at work. From the six items that are most dominant or have the highest mean value is item number 1 that is equal to 4.25 which means most of the respondents have good relationships with colleagues working environment.

The overall mean value of fun at work with celebrating at work dimensions is 2.44 , the values are between $1.81-2.60$ which means that some respondents have low celebrating at work. By the six items, the most dominant or have the highest mean value is item number 2 that is equal to 2.85 which means most of the respondents only occasionally hold a gathering or outbound event every year. 
The overall mean value of fun at work dimensions of personal freedoms has a mean value of 2.15 , the values are between $1.81-2.60$ which means that some respondents have low personal freedoms. By the six items, the most dominant or having the highest mean value is item number 1 which is equal to 2.49 , this means most respondents rarely have right to wear any clothes.

Tablel 2. Description of respondents response for fun at work variable

\begin{tabular}{|c|c|c|c|c|c|c|c|c|}
\hline No & Statement & 1 & 2 & 3 & 4 & 5 & Mean & Precentage \\
\hline & SOCIALIZING WITH COWORKER & & & & & & & \\
\hline 1 & Socialization among workers at work & 0 & 1 & 4 & 38 & 22 & 4.24 & $84.90 \%$ \\
\hline 2 & $\begin{array}{l}\text { Socialization between workers outside the } \\
\text { workplace }\end{array}$ & 0 & 0 & 13 & 41 & 11 & 3.97 & $79.40 \%$ \\
\hline 3 & Friendship at work & 0 & 3 & 14 & 39 & 9 & 3.83 & $76.62 \%$ \\
\hline 4 & Share stories & 0 & 1 & 17 & 30 & 17 & 3.97 & $79.38 \%$ \\
\hline 5 & Jokes between workers & 0 & 0 & 16 & 38 & 11 & 3.92 & $78.50 \%$ \\
\hline \multirow[t]{3}{*}{6} & Sharing food among workers & 0 & 0 & 17 & 43 & 5 & 3.82 & $76.30 \%$ \\
\hline & Total mean & & & & & & 3.96 & $79.18 \%$ \\
\hline & CELEBRATING AT WORK & & & & & & & \\
\hline 1 & Celebration at work & 6 & 36 & 21 & 2 & 0 & 2.29 & $45.80 \%$ \\
\hline 2 & $\begin{array}{l}\text { The Company annually holds a gathering } \\
\text { or outbound event }\end{array}$ & 0 & 20 & 35 & 10 & 0 & 2.85 & $56.90 \%$ \\
\hline 3 & Office parties (Dining events) & 0 & 26 & 32 & 7 & 0 & 2.71 & $54.20 \%$ \\
\hline 4 & Birthday events and other events & 4 & 38 & 20 & 3 & 0 & 2.34 & $46.80 \%$ \\
\hline 5 & Award for achievement & 6 & 32 & 26 & 1 & 0 & 2.34 & $47 \%$ \\
\hline \multirow[t]{3}{*}{6} & Holiday Time Celebration Event & 13 & 33 & 18 & 1 & 0 & 2.11 & $42 \%$ \\
\hline & Total Mean & & & & & & 2.44 & $48.77 \%$ \\
\hline & PERSONAL FREEDOMS & & & & & & & \\
\hline 1 & Freedom of Dressing & 16 & 15 & 21 & 12 & 1 & 2.49 & $49.85 \%$ \\
\hline 2 & Being allowed to listen to music in private & 29 & 17 & 12 & 7 & 0 & 1.95 & $39.10 \%$ \\
\hline 3 & Taking a break from working hours & 18 & 21 & 15 & 10 & 1 & 2.31 & $46.15 \%$ \\
\hline 4 & Having lunch with co-workers & 14 & 24 & 22 & 5 & 0 & 2.28 & $45.54 \%$ \\
\hline 5 & Autonomy / freedom at work & 28 & 21 & 12 & 4 & 0 & 1.88 & 37.54 \\
\hline \multirow[t]{3}{*}{6} & Playing at workplace & 27 & 17 & 16 & 4 & 1 & 2 & $40 \%$ \\
\hline & Mean Total & & & & & & 2.15 & $43.03 \%$ \\
\hline & GLOBAL FUN AT WORK & & & & & & & \\
\hline 1 & Office is a fun place to work & 0 & 0 & 29 & 32 & 4 & 3.62 & $72.30 \%$ \\
\hline 2 & The boss looks fun & 0 & 0 & 31 & 33 & 1 & 3.54 & $70.80 \%$ \\
\hline 3 & The company has a nice atmosphere & 0 & 0 & 25 & 33 & 7 & 3.72 & $74 \%$ \\
\hline 4 & Most employees feel happy at work & 0 & 0 & 26 & 36 & 3 & 3.65 & $72.90 \%$ \\
\hline 5 & $\begin{array}{l}\text { The overall atmosphere in the company is } \\
\text { very pleasant }\end{array}$ & 0 & 0 & 28 & 35 & 2 & 3.6 & $72 \%$ \\
\hline \multirow[t]{2}{*}{6} & Bosses encourage workplace fun & 0 & 0 & 30 & 34 & 1 & 3.55 & $71.10 \%$ \\
\hline & Total Mean & & & & & & 3.61 & $72.30 \%$ \\
\hline
\end{tabular}

The overall mean value of fun at work in global dimension of fun at work has a mean value of 3.61 which are between $3.41-4.20$, this means that some respondents have a high global fun at work. 
By the six items that are most dominant or have the highest mean value is item number 3 that is equal to 3.72 which means most respondents agree that the company has a fun atmosphere.

\begin{tabular}{lllllllll} 
Table & 3. Description of Respondents' Response to Job Engagement Variable \\
\hline No & Statement & 1 & 2 & 3 & 4 & 5 & Mean & Precentage \\
\hline 1 & Energy Level & 0 & 1 & 13 & 43 & 8 & 3.89 & $77.80 \%$ \\
2 & High endurance & 0 & 2 & 12 & 43 & 8 & 3.87 & $77.54 \%$ \\
3 & Willingness to invest business & 0 & 2 & 26 & 30 & 7 & 3.65 & $72.90 \%$ \\
4 & Feelings of enthusiastic & 0 & 3 & 29 & 28 & 5 & 3.54 & $70.80 \%$ \\
5 & Being proud of the work that have been done & 0 & 2 & 31 & 24 & 8 & 3.58 & $71.70 \%$ \\
6 & Felling challenged & 0 & 4 & 25 & 29 & 7 & 3.6 & $72.00 \%$ \\
7 & Overall feeling good at work & 0 & 1 & 13 & 40 & 11 & 3.94 & $79.00 \%$ \\
8 & Comfort with work atmosphere to make time & 0 & 5 & 29 & 20 & 11 & 3.57 & $71.38 \%$ \\
9 & pass very fast & & & & & & & \\
9 & Working hard and forget anything else around & 0 & 0 & 17 & 40 & 8 & 3.86 & $77.23 \%$ \\
\hline & Total Mean & & & & & & 3.72 & $74.46 \%$ \\
\hline
\end{tabular}

In table 3. the overall job involvement variable has an average value of 3.72 , the value are between $3.41-4.20$ which means that most respondents have a high level of work engagement. By the nine items, the most dominant one is item number 7 which means most of the respondents overall feel happy at work.

Table 4. Description of Respondents' Response to Job Satisfaction Variables

\begin{tabular}{clccccccc}
\hline No & Statement & 1 & 2 & 3 & 4 & 5 & Mean & Precentage \\
\hline 1 & Job satisfaction & 0 & 5 & 29 & 24 & 7 & 3.51 & $70.15 \%$ \\
2 & Liking work at the workplace & 0 & 6 & 28 & 29 & 2 & 3.41 & $68.31 \%$ \\
3 & Disliking work at the workplace & 0 & 7 & 31 & 27 & 0 & 3.31 & $66.15 \%$ \\
\hline & Total Mean & & & & & & 3.41 & $68.20 \%$ \\
\hline
\end{tabular}

In table 4. overall job satisfaction variabel has an average value of 3.41 , this value lies between 3.41 - 4.20 which means that respondents mostly have a high level of job satisfaction. From the three items above, the most dominant is the number 1 which means most respondents agree with the statement as a whole that they were satisfied with their work

\section{Validity and Reliability Test}

Validity test used in this research is confirmatory factor analysis (CFA). According to Hair et al., (1998), Loading factor $\geq 0.50$ is considered significant. The value of KMO Measure of Sampling Adequency (MSA) is 0.728 which means the value of MSA in this study is above 0.5 and Bartlestt's Test with Chi-squaressignificant is at 0,000 , this indicates that the test of the factor analysis is qualified. All question items are stated valid, because each item of question that becomes indicator of each variable has been extracted perfectly and has a loading factor $\geq 0.50$.

Reliability values of variable can be measured using SPSS by performing cronbach alpha statistical tests. A variable could be stated as reliable if the cronbach alpha coefficient $>0.60$ (Ghozali, 2005). Based on table 5., it can be seen that the variables of socializing at work, celebrating at work, personal freedoms, global fun at work, work engangement, job satisfaction have coefficient of cronbach alpha $>0.6$ which means that the reliability is good. 
Table 5. Result of reliability test by factor analysis

\begin{tabular}{lcl}
\hline Variables & $\mathrm{r}$ alpha & Explanation \\
\hline Fun at work & & \\
Socializing At Work & 0.888 & Reliable \\
Celebrating At Work & 0.860 & Reliable \\
Personal Freedoms & 0.821 & Reliable \\
Global Fun at work & 0.850 & Reliable \\
Work Engangement & 0.895 & Reliable \\
Job Satisfaction & 0.666 & Reliable \\
\hline
\end{tabular}

This study used regression method to verify the hypothesis based on research conducted by Barron and Kenny (1986). In this test there are three regression models: (1) the independent variable (Fun at work) regressed with the mediation variable (Job Involvement); (2) the independent variable (Fun at work) regressed with the dependent variable (Job Satisfaction); (3) the independent variables (Fun at work) and the mediation variables (work involvement) regressed with the dependent variable (Job Satisfaction).

Table 6. Baron \& Kenny (1986) Regression Test Results

\begin{tabular}{llrrrrr} 
& \multicolumn{2}{c}{ Model 1 } & \multicolumn{2}{c}{ Model 2 } & \multicolumn{2}{c}{ Model 3 } \\
& \multicolumn{2}{c}{ Job Engagement } & \multicolumn{2}{c}{ Job satisfaction } & \multicolumn{2}{c}{ Job satisfaction } \\
& $\mathrm{t}$ & $\mathrm{Sig}$ & $\mathrm{t}$ & $\mathrm{Sig}$ & $\mathrm{t}$ & $\mathrm{Sig}$ \\
\hline (Constant) & 0.765 & 0.447 & 0.412 & 0.682 & 0.153 & 0.879 \\
Socializing with Coworkers & $2.295^{* *}$ & 0.025 & $2.275^{* *}$ & 0.026 & 1.498 & 0.140 \\
Celebrating at work & $2.881^{* * *}$ & 0.005 & $2.140^{* *}$ & 0.036 & 1.128 & 0.264 \\
Personal Freedoms & $2.377^{* *}$ & 0.021 & $2.605^{* *}$ & 0.012 & $1.798^{*}$ & 0.077 \\
Global Fun at Work & $2.140^{* *}$ & 0.036 & $2.069^{* *}$ & 0.043 & 1.350 & 0.182 \\
Job Engagement & & & & & $2.850^{*}$ & 0.006 \\
R adjusted & 0.468 & & 0.418 & & 0.480 & \\
F arithmetic & 15.096 & & 12.499 & & 12.811 & \\
\hline
\end{tabular}

Notes: $*, * *$, and $* * *$ denotes significance in $\mathrm{p}<0.1, \mathrm{p}<0.05$, and $\mathrm{p}<0.01$

Table 6. shows that in model 1, socializing with coworkers, celebrating at work, personal freedoms, global fun at work effect on job engagement with significance level $\mathrm{P}<0.05$; then hypothesis 1 is supported in this study. Adjusted $\mathrm{R}^{2}$ of 0.468 means that $46.8 \%$ job engagement variables can be explained by socializing with coworkers, celebrating at work, personal freedoms, global fun at work variables. The remaining $53.2 \%$ can be explained by other variables which are not included in this research model.

The results shows that fun at work positively affects on job involvement. This phenomenon can occur because a fun workplace will fully affect the emotional, and physical person in doing the job. A person who feels happy will feel more enthusiastic in doing his job so as to provide optimal results for the company. The results of this study support the research conducted by Jamaludin et al. (2014) which says that there is intermediate influence of fun at work and work engangement. If fun at work increases then work engangement will also increase.

Model 2 shows socializing with coworkers, celebrating at work, personal freedoms, global fun at work effect on job satisfaction with significance level $\mathrm{P}<0.05$; This means that hypothesis 2 is supported in this study. Adjusted $\mathrm{R}^{2}$ of 0.418 ; means that $41.8 \%$ of job satisfaction variables can be explained by socializing with coworkers, celebrating at work, personal freedoms, global fun at work. The remaining $58.2 \%$ can be explained by other variables which are not included in this research model.

The results shows that fun at work positively influences on employee satisfaction. This phenomenon can occur because a fun workplace will fully affect the positive feelings associated with workplace pleasure in influencing one's feelings. Employees who feel happy at work will feel more 
motivated in doing their work and will have greater satisfaction with their work. The results of this study support the research conducted by Lamm and Meeks (2009), One of the factors that influences the job satisfaction behavior is a fun workplace (Fun at work). Fluegge (2014) fun at work is crucial in shaping a positive environment. A positive environment can affect a person's mood for the better.

Model 3 shows that work engagement, has an effect on job satisfaction with significance level of $\mathrm{P}<0.05$; Then hypothesis 3 is supported in this study. Model 3 also shows that socializing with coworkers, celebrating at work, personal freedom, global fun at work have no effect on job satisfaction if work engagement is included in the regression equation. The influence of mediation variable of work engagement in this research is full mediation, because in model 3, the influence of socializing with coworkers, celebrating at work, personal freedoms, global fun at work become insignificant. Adjusted $\mathrm{R}^{2}$ of 0.48 ; means that $48 \%$ of job satisfaction variables can be explained by socializing with coworkers, celebrating at work, personal freedoms, global fun at work variables. The remaining $52 \%$ can be explained by other variables which are not included in this research model.

These results indicate that employee engagement mediates the influence of fun at work on job satisfaction. This phenomenon can occur because a fun workplace can stimulate a good mood and excitement for employees in doing their job. This result supports research conducted by Fluegge (2014), which states "If fun in the workplace can improve work engagement, which positively affects the outcome of the performance, so that the work engagement mediates the relationship between workplace enjoyment and performance results. Individuals who feel fun at work often tend to engage in work and will further have an effect on greater and creative performance.

\section{Conclusion}

Based on the results of the research analysis that has been described previously and supported by the data obtained, therefore, it can be concluded that fun at work has a direct effect on employment engagement. This means higher fun at work will increase one's involvement in work. Fun at work has a direct effect on job satisfaction. This can be seen with the high value on socializing at work and global fun at work at the company. Work engagement indirectly mediates between fun at work and job satisfaction. This means that an employee feels fun in the workplace tends to be more involved in their work, and this indirectly affects job satisfaction.

Since these questionnaires were conducted during break time, this could cause employees to collude in filling them out. As a result, they could have similar answers. Although they have been distributed regularly every day, researchers still can not control the overall employees in filling out the questionnaires due to limited time. The use of Likert Scale to evaluate the questionnaires allows the respondent to have a neutral attitude in choosing the answer. If the respondent is lack of understanding of the question then they could choose the neutral option in answering the questions that the researchers provide.

\section{References}

Barron, R.. and Kenny, D.. (1986), “The Moderator-Mediator Variable Distinction in Social Psychological Research: Conceptual, Strategic and Statistical Condiderations”, Journal of Personality and Social Psychological, Vol. 51, pp. $1173-1182$.

Fluegge, E.. (2008), "Who put the fun in functional? Fun at work and its effect on job performance", Business Administration.

Fluegge, E.. (2014), "Play hard, work hard Fun at work and job performance", Management Research Review, Vol. 37 No. 8, pp. 682-705.

Ghozali, I. (2005), Aplikasi Analisis Multivariate Dengan Program SPSS, Ketiga., Badan Penerbit Universitas Diponegoro, Semarang.

Hair, J.F.J., Anderson, R.., Tatham, R.. and Black, W.. (1998), Multivariate Data Analysis, Fifth., Prentice Hall Inc, Upper Sanddle River, New Jersey.

In, C.Y. and Ching, Y.H. (2010), "Workplace fun and Job Satisfaction: the Moderating effects of Attitudes toward Fun”, Human Resources Management.

Jamaludin, M.., Ahmad, A.., Mohammad, A. and Shobri, N.D.. (2014), "A Study on the Relationship Between Fun at Work and Work Engagement”, Proceedings of the ASEAN Entrepreneurship Conference.

Lamm, E. and Meeks, M.D. (2009), "Workplace fun: the moderating effects of generational differences", Employee Relations, Vol. 31 No. 6, pp. 613-631. 
McDowell, T. (2014), Fun at Work. Scale Development, Confirmatory Factor Analysis and Links to Organizational Outcomes, Alliant International University.

Schaufeli, W.. (2013), "Whats is engagement? In C. Truss, K. Alfes, R. Delbridge, A. Shantz, \& E. Soane (Eds)”, Employe Engagement in Theory and Practice, Routledge, London.

Yanti. (2013), Pengaruh Workplace Fun Terhadap Kinerja Karyawan Berdasarkan Generational Differences (Studi Pada PT. BXY), Universitas Indonesia. 